\title{
EVALUASI PENGENDALIAN INTERNAL DAN SISTEM AKUNTANSI ATAS PENERIMAAN KAS DAN PIUTANG PREMI ASURANSI PADA PT H
}

\author{
Nena Seoulinda; Aries Wicaksono \\ Accounting Department, Faculty of Economic and Communication, BINUS University \\ Jln. K.H. Syahdan No.9, Kemanggisan-Palmerah, Jakarta 11480 \\ aries.wicaksono@binus.ac.id
}

\begin{abstract}
PT H is an insurance company that only serves a group of life insurance. The purpose of this research is to evaluate the entity's internal control and accounting system on cash receipt and insurance premium receivables. To conduct the research, the researcher used a method based on Committe of Sponsoring Organization or usually known as COSO. The data were collected from literatures such as textbooks, and other references, such as theories and scientific opinions related to this topic. Apart from the theories, researcher performed interviews, spread questionnaries, and observations to the entity. The internal control and accounting system in PT H has been well organized by the management and in accordance with the standards and the Entity's policy. But other than that, the researcher found several weakness that should be a concern of management, especially on the Entity's documentation and the delivery of information. Therefore, the researcher recommends that serial number in documents such as receipt, payment request form, and accounting request form should have been printed; to create a new company policy related to the delivery and receiving of files; and to make a written rules related to the Entity's code of ethics and rules how to deliver information between sections and subsections.
\end{abstract}

Keywords: evaluation, internal control, accounting system, cash receipt, insurance premium receivables

\begin{abstract}
ABSTRAK
PT H merupakan perusahaan asuransi yang hanya melayani asuransi jiwa kumpulan. Tujuan penelitian ini adalah untuk mengevaluasi pengendalian internal dan sistem akuntansi atas penerimaan kas dan piutang premi pada perusahaan. Untuk melakukan evaluasi tersebut peneliti menggunakan metode yang didasari oleh Committee of Sponsoring Organization atau biasa dikenal dengan COSO. Data diperoleh dari literatur yang antara lain, buku teks, dan sumber referensi lain berupa teori-teori dan pendapat ilmiah lainnya yang berhubungan dengan topik pembahasan. Selain berdasarkan teori-teori, peneliti melakukan wawancara, menyebar kuesioner, dan observasi ke perusahaan. Pada PT H pengendalian internal dan sistem akuntansi yang disusun oleh manajemen sudah baik dan sesuai dengan standar dan kebijakan yang dibuat oleh perusahaan. Selain itu telah ditemukan beberapa kelemahan yang harus menjadi perhatian manajemen, terutama pada dokumentasi dan penyampaian informasi. Sehingga peneliti merekomendasikan pembuatan nomor tercetak pada dokumen Kwitansi, Permintaan Pembayaran, dan Permintaan Pembukuan; pembuatan kebijakan baru yang berhubungan dengan pengiriman berkas-berkas kelengkapan; serta membuat peraturan secara tertulis kode etik dan cara penyampaian informasi antar bagian dan subbagian.
\end{abstract}

Kata kunci: evaluasi, pengendalian intern, sistem akuntansi, penerimaan kas, piutang premi 


\section{PENDAHULUAN}

Salah satu cara penanggulangan risiko adalah dengan mengasuransikan suatu risiko kepada perusahaan asuransi. Asuransi artinya transaksi pertanggungan, yang melibatkan dua pihak, tertanggung dan penanggung. Definisi Asuransi menurut pasal 246 Kitab Undang-Undang Dagang (KUHD) Republik Indonesia: "Asuransi atau pertanggungan adalah suatu perjanjian dimana seorang penanggung mengikatkan diri pada tertanggung dengan menerima suatu premi untuk memberikan penggantian kepadanya karena suatu kerugian, kerusakan atau kehilangan keuntungan yang diharapkan mungkin akan dideritanya karena suatu peristiwa yang tak tentu.” Perusahaan asuransi adalah lembaga keuangan non-bank yang memiliki peranan serupa dengan bank, yaitu bergerak dalam bidang layanan jasa yang diberikan kepada masyarakat dalam mengatasi risiko yang akan terjadi pada masa yang akan datang. Perusahaan asuransi memiliki perbedaan karakteristik dengan perusahaan non-asuransi seperti underwriting - actuarial, claim, dan reassurance -retrosesi.

Penjamin (underwriting) adalah proses penaksiran atau penilaian dan penggolongan derajat risiko yang terkait pada calon tertanggung, serta pembuatan keputusan untuk menerima atau menolak risiko tersebut. Aktuaria (Actuarial) adalah fungsi pada suatu perusahaan asuransi yang menerapkan prinsip-prinsip matematika pada asuransi, termasuk mengkalkulasi atau memperhitungan daftar harga premi serta memastikan kesehatan perusahaan dari segi keuangan. Claim adalah beban yang menjadi kewajiban perusahaan asuransi terhadap pemegang polis (konsumen) akibat terjadi peristiwa yang diasuransikan atau yang telah jatuh tempo. Reassurance adalah pihak yang menerima pertanggungan ulang dari suatu penutupan asuransi. Retrosesi adalah pelimpahan risiko dari perusahaan reasuransi kepada perusahaan reasuransi lainnya.

Pada saat penanggung menjamin pihak tertanggung, bahwa ia akan mendapatkan penggantian terhadap suatu kerugian yang mungkin akan dideritanya, sebagai akibat dari suatu peristiwa yang semula belum tentu akan terjadi atau yang semula belum dapat ditentukan saat atau kapan terjadinya. Sebagai kontraprestasi, tertanggung diwajibkan membayar sejumlah uang kepada penanggung, yang besarnya sekian persen dari nilai pertanggungan, yang biasa disebut "premi".

Kas merupakan alat pembayaran yang siap dan bebas digunakan untuk membiayai kegiatan umum, alat pembayaran yang digunakan untuk pelunasan utang, dan dapat diterima sebagai setoran dalam jumlah sebesar nilai nominalnya, juga simpanan bank atau tempat lain yang dapat diambil. Kas sangatlah penting karena dapat menggambarkan daya beli perorangan, entitas, dan bahkan pemerintah harus mempertahankan posisi likuiditas yang memadai. Kas juga berlaku sebagai alat tukar dalam perekonomian kita, serta secara langsung maupun tidak langsung ada dalam hampir semua transaksi perusahaan.

Semua transaksi penerimaan kas yang berjumlah besar harus dilakukan dengan cek yaitu melalui bank, sedangkan penerimaan tunai yang jumlahnya relatif kecil dilakukan melalui kas kecil. Kas sangat mudah digunakan sehingga sangat rawan untuk disalahgunakan. Kesalahan atau penyimpangan terhadap kas di tangan (petty cash) biasanya melibatkan pihak-pihak intern perusahaan terutama di Bagian Kas. Kas merupakan suatu aset perusahaan yang paling gemar dicurangi, karena kas tidak memiliki kepemilikan, mudah untuk diambil dan digunakan, serta rawan terjadi lapping dan kitting.

Dengan tambah kompleksnya tugas-tugas manajemen, mereka tidak mampu melakukan pengawasan dan koordinasi yang efektif untuk seluruh perusahaan. Hal tersebut dapat berdampak buruk kepada perusahaan. Untuk itu, pihak manajemen perusahaan akan membuat perencanaan dan kebijakan agar dapat mencapai tujuan perusahaan. Dengan adanya perencanaan dan dan kebijakan yang sesuai dan dapat digunakan secara langsung maka efisiensi dan efektivitas kerja dapat terlaksana dan perusahaan mampu bersaing dengan perusahaan sejenis lainnya. 
Dalam teori akuntansi dan organisasi, pengendalian internal atau yang biasa disebut internal control didefinisikan sebagai suatu proses, yang dipengaruhi oleh sumber daya manusia dan sistem teknologi informasi, yang dirancang untuk membantu organisasi mencapai suatu tujuan atau objektif tertentu. Pengendalian internal merupakan suatu cara untuk mengarahkan, mengawasi, dan mengukur sumber daya suatu organisasi. Pengendalian internal berperan penting untuk mencegah dan mendeteksi penggelapan (fraud) dan melindungi sumber daya organisasi baik yang berwujud (seperti mesin dan lahan) maupun tidak (seperti reputasi atau hak kekayaan intelektual seperti merek dagang).

Dengan adanya sistem akuntansi yang memadai, akuntan perusahaan dapat menyediakan informasi keuangan yang dapat diandalkan bagi setiap tingkatan manajemen, para pemilik atau pemegang saham, kreditur dan para pemakai laporan keuangan (stakeholder) lain yang dijadikan dasar pengambilan keputusan ekonomi. Sistem tersebut dapat digunakan oleh manajemen untuk merencanakan dan mengendalikan operasi perusahaan. Lebih rinci lagi, kebijakan dan prosedur yang digunakan secara langsung dimaksudkan untuk mencapai sasaran dan menjamin atau menyediakan laporan keuangan yang tepat serta menjamin ditaatinya atau dipatuhinya hukum dan peraturan. Hal ini disebut sebagai "pengendalian intern", atau dengan kata lain bahwa pengendalian intern terdiri atas kebijakan dan prosedur yang digunakan dalam operasi perusahaan untuk menyediakan informasi keuangan yang andal serta menjamin dipatuhinya hukum dan peraturan yang berlaku.

Sebagai bahan referensi bagi peneliti selanjutnya-yang tertarik tentang pengendalian internal dan sistem akuntansi perusahaan, khususnya dalam penerimaan kas dan piutang premi asuransi, dalam literatur yang ada mengenai pengendalian internal atau internal control menurut Mulyadi (2004), adalah salah satu unsur penting dari test of control. Unsur-unsur tersebut adalah sistem akuntansi, unsur pengendalian internal, kuesioner pengendalian internal, dan program pengujian pengendalian internal. Sedangkan menurut Messier, Glover, dan Prawitt (2006) pengendalian internal didesain dan dipengaruhi oleh entitas dewan direksi, manajemen, dan personel lainnya untuk memberikan keyakinan pencapaian tujuan entitas dalam kategori sebagai berikut: reliabilitas dari laporan keuangan, efektivitas dan efisiensi operasional, dan kepatuhan terhadap peraturan dan hukum yang berlaku.

Berdasarkan literatur di atas, pengendalian internal adalah struktur organisasi, metode, dan ukuran yang dikoordinasikan untuk menjaga kekayaan organisasi, mengecek ketelitian dan keandalan laporan keuangan, mendorong efisiensi dan efektivitas operasi, serta mendorong dipatuhinya kebijakan manajemen untuk melakukan tujuan yang telah ditentukan dan bukan unsur-unsur yang membentuk sistem tersebut.

Kerangka atau model pengendalian internal yang lazim digunakan yaitu model COSO (The Committee of Sponsoring Organization). Menurut Elder, Beasly, Arens dan Jusuf (2011) dan Jusuf, pengendalian internal model COSO (2011: 321) memiliki kerangka pengendalian internal yang paling banyak digunakan menjelaskan lima komponen pengendalian internal yang dirancang dan diterapkan manajemen untuk memberikan keyakinan yang memadai bahwa tujuan-tujuan pengendaliannya dapat terpenuhi. Masing-masing komponen berisi banyak pengendalian yang dirancang untuk mencegah atau mendeteksi salah saji material dalam laporan keuangan. Berikut ini merupakan gambar komponen pengendalian internal.

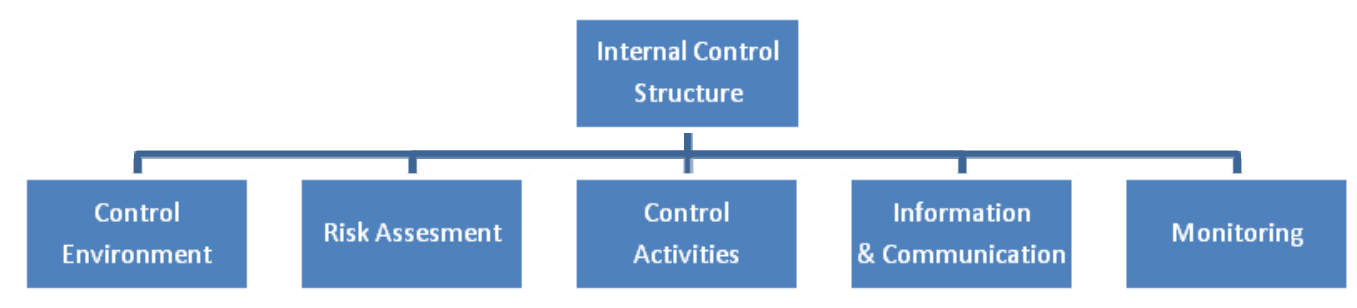

Gambar 1 Komponen Pengendalian Internal 
Untuk mengevaluasi suatu pengendalian internal, menurut Agoes (2004), dalam organisasi dapat dilakukan dengan menggunakan beberapa instrumen antara lain: (i) Internal Control Questionnaire (ICQ); instrumen ini biasanya digunakan oleh KAP untuk mengevaluasi pengendalian internal dari klien. Instrumen ini digunakan karena lebih sederhana dan praktis. (ii) Flowchart (Bagan arus); instrumen ini biasanya digunakan untuk menggambarkan proses bisnis dalam suatu unit usaha. Auditor yang menggunakan flowchart merupakan auditor yang sudah terlatih. Dengan menggunakan flowchart, kelemahan yang ada lebih mudah untuk dianalisis. (iii) Uraian Cerita (Narrative); instrumen ini biasanya digunakan untuk menggambarkan proses bisnis dari suatu organisasi yang memiliki proses bisnis yang sederhana.

Sistem Akuntansi secara luas dapat terkait ke dalam sistem lain dalam suatu organisasi. Menurut Warren, Reeve, dan Fess yang diterjemahkan oleh Farahmita, Amanugrahani, dan Hendrawan (2005: 226), sistem akuntansi adalah metode dan prosedur untuk mengumpulkan, mengklasifikasikan, mengikhtiarkan, dan melaporkan informasi operasi dan keuangan sebuah perusahaan.

Kemudian mengenai kas ada beberapa hal yang penting yaitu pengertian mengenai batasan kas itu sendiri dan pengendalian internal atas kas. Pengertian kas menurut IAI (2010: 02) kas terdiri dari saldo kas (cash on hand) dan rekening giro. Arus masuk dan arus keluar kas atau setara kas disebut arus kas. Cash on hand adalah saldo kas yang ada ditangan perusahaan (biasa disebut dengan Kas saja), sedang rekening giro adalah kas yang ada di Bank (disebut dengan Kas Bank atau Bank saja).

Mengacu kepada pendapat Mulyadi (2004: 455), pengertian penerimaan kas adalah kas yang diterima perusahaan, baik yang berupa uang tunai maupun surat-surat berharga yang mempunyai sifat dapat segera digunakan, yang berasal dari transaksi perusahaan, maupun penjualan tunai, pelunasan piutang atau transaksi lainnya yang dapat menambah kas perusahaan: "Sumber penerimaan kas terbesar suatu perusahaan dagang berasal dari transaksi penjualan tunai." Berdasarkan sistem pengendalian intern yang baik, sistem penerimaan kas dari penjualan tunai mengharuskan:Penerimaan kas dalam bentuk tunai harus segera disetor ke bank dalam jumlah penuh dengan cara melibatkan pihak lain selain kasir untuk melakukan internal check. Penerimaan kas dari penjualan tunai dilakukan melalui transaksi kartu kredit, yang melibatkan bank penerbit kartu kredit dalam pencatatan transaksi penerimaan kas.

Pengertian premi menurut PSAK No.36 (2010) Akuntansi Asuransi Jiwa, premi merupakan pendapatan perusahaan akuntansi, disamping hasil investasi yang menjadi kegiatan tidak terpisahkan dari asuransi jiwa. Premi merupakan salah satu sumber penerimaan dalam perusahaan asuransi yang berupa hadiah atau derma, atau suatu pembayaran tambahan diatas pembayaran normal yang harus dibayar setiap bulan.

Piutang merupakan suatu proses yang penting, yang dapat menunjukkan satu bagian yang besar dari harta likuid perusahaan. Kieso dan Weygandt (2008) mendefinisikan pengertian piutang sebagai: "receivables are claims held against customers and others for money, goods, or services." Menurut Mulyadi (2002), pengendalian piutang dimulai sebelum adanya persetujuan untuk mengirimkan barang, sampai setelah penyiapan dan penerbitan faktur, dan berakhir dengan penagihan dan penjualan. Prosedur pengendalian piutang tersebut berhubungan erat dengan pengendalian penerimaan kas dan pengendalian persediaan, sehingga piutang merupakan suatu penghubung yang ada diantara keduanya.

Bila ditinjau dari pendekatan manajemen secara preventif, ada tiga bidang pengendalian yang umum pada titik mana dapat diambil tindakan. Ketiga bidang tersebut adalah: pertama, Pemberian Kredit Dagang; kebijaksaan kredit dan syarat penjualan harus tidak menghalangi penjualan kepada 
para pelanggan yang sehat keadaan keuangannya, dan juga tidak boleh menimbulkan kerugian yang besar karena adanya piutang sangsi yang berlebihan. Kedua, Penagihan (Collection); apabila telah diberikan kredit, perusahaan harus melakukan berbagai usaha untuk memperoleh pembayaran yang sesuai dengan syarat penjualan dalam waktu yang wajar. Ketiga, Penetapan dan Penyelenggaraan Pengendalian Intern; meskipun prosedur pemberian kredit dan penagihan telah diadministrasikan dengan baik atau dilakukan secara wajar, tidak dapat menjadi jaminan adanya pengendalian piutang. Yaitu, tidak menjamin bahwa semua penyerahan memang difaktur, atau difaktur sebagaimana mestinya kepada para pelanggan dan bahwa penerimaan benar-benar masuk ke dalam rekening bank perusahaan.

Dari teori-teori yang digunakan, dapat disimpulkan kajian teoritis atas evaluasi yang akan dilakukan oleh peneliti pada Tabel 1.

Tabel 1 Rangkuman Kajian Teoritis

\begin{tabular}{|c|c|c|}
\hline Sumber Teori & Penjelasan & Hubungan \\
\hline $\begin{array}{l}\text { Pasal } 246 \text { Kitab Undang- } \\
\text { Undang Dagang (KUHD) } \\
\text { Republik Indonesia }\end{array}$ & $\begin{array}{l}\text { Asuransi atau pertanggungan adalah suatu } \\
\text { perjanjian dimana seorang penanggung } \\
\text { mengikatkan diri pada tertanggung dengan } \\
\text { menerima suatu premi untuk memberikan } \\
\text { penggantian kepadanya karena suatu kerugian, } \\
\text { kerusakan atau kehilangan keuntungan yang } \\
\text { diharapkan mungkin akan dideritanya karena } \\
\text { suatu peristiwa yang tak tentu }\end{array}$ & $\begin{array}{l}\text { Dalam hal ini perusahaan } \\
\text { asuransi merupakan objek } \\
\text { penelitian yang dipilih oleh } \\
\text { peneliti dalam rangka menilai } \\
\text { kinerja dan keefektifan Sistem } \\
\text { Akuntansi yang digunakan } \\
\text { khususnya pada penerimaan } \\
\text { kas dan piutang premi asuransi. }\end{array}$ \\
\hline $\begin{array}{l}\text { Menurut Messier, Glover, dan } \\
\text { Prawitt (2006:220) }\end{array}$ & $\begin{array}{l}\text { Internal control is designed and affected by an } \\
\text { entity's board of directors, management, and } \\
\text { other personnel to provide reasonable } \\
\text { assurance about the achievenment of the } \\
\text { entity's objectives in the following categories: } \\
\text { (1) reliability of financial reporting, (2) } \\
\text { effectiveness and efficiency of operations, and } \\
\text { (3) compliance with applicable laws and } \\
\text { regulations. }\end{array}$ & $\begin{array}{l}\text { Tujuan tersebut akan } \\
\text { digunakan sebagai tolak ukur } \\
\text { tercapai atau tidaknya } \\
\text { penerapan pengendalian intern } \\
\text { pada PT H. }\end{array}$ \\
\hline Menurut Mulyadi (2002 : 218) & $\begin{array}{l}\text { Unsur-unsur perancangan pengujian (test of } \\
\text { control): } \\
\text { 1. Sistem Akuntansi } \\
\text { 2. Unsur Pengendalian Intern } \\
\text { 3. Kuesioner Pengendalian Intern } \\
\text { 4. Program Pengujian Pengendalian Intern }\end{array}$ & $\begin{array}{l}\text { Evaluasi pengendalian internal } \\
\text { dengan cara penyebaran } \\
\text { kuisioner, penilaian flowchart, } \\
\text { dan narasi atas prosedur yang } \\
\text { digunakan untuk menilai } \\
\text { keefektifan pengendalian } \\
\text { internal yang telah diterapkan. }\end{array}$ \\
\hline $\begin{array}{l}\text { Elder, Beasly, Arens, dan Jusuf } \\
\text { pengendalian intern model } \\
\text { COSO (2011:321) }\end{array}$ & $\begin{array}{l}\text { Komponen COSO adalah sebagai berikut: } \\
\text { 1. Lingkungan Pengendalian } \\
\text { 2. Penilaian Risiko } \\
\text { 3. Pengendalian Fisik } \\
\text { 4. Informasi dan Komunikasi } \\
\text { 5. Pengawasan }\end{array}$ & $\begin{array}{l}\text { Komponen COSO tersebut } \\
\text { merupakan dasar dari } \\
\text { penelitian dan evaluasi. }\end{array}$ \\
\hline
\end{tabular}

\section{METODE PENELITIAN}

Metode yang digunakan dalam penelitian ini adalah metode deskriptif, dengan melakukan wawancara dan kuesioner. Penelitian deskriptif dilakukan dengan meneliti pengendalian internal yang berupa prosedur, kebijakan, dan aturan yang ada pada PT. H. Kemudian, peneliti mengevaluasinya berdasarkan permasalahan yang ada selama ini terjadi dengan menghubungkannya satu sama lain baik dari sisi prosedur, kebijakan, serta aturan. Kuesioner digunakan untuk menggali data dan informasi 
secara umum. Lalu, wawancara digunakan untuk memperoleh gambaran langsung yang lebih mendalam dari pelaku dalam penerimaan kas dan piutang premi yang ada pada PT. H. Dengan kedua metode tersebut, dapat dihasilkan gambaran permasalahan yang selama ini terjadi serta kendala untuk mengatasi permasalahan tersebut.

\section{HASIL DAN PEMBAHASAN}

Evaluasi dan analisis yang dilakukan mengenai pengendalian internal serta sistem akuntansi secara umum pada penjualan, penerimaan kas, dan piutang premi pada PT. H. Analisis dilakukan terhadap lima komponen pengendalian COSO dan evaluasi pengendalian secara umum terhadap pengendalian internal dan sistem akuntansi.

\section{Evaluasi Pengendalian Internal dan Sistem Akuntansi secara Umum PT. H}

Evaluasi terhadap pengendalian internal secara umum, didapatkan fakta-fakta atas aktivitas di PT. H. Terdapat fakta yang merupakan kelebihan, dan ada fakta yang merupakan kelemahan. Faktafakta yang diperoleh adalah sebagai berikut. PT. H menekankan kejujuran, ketertiban waktu dalam bekerja, dan ketepatan waktu dalam menyelesaikan tugas. Hal tersebut terlihat dari tingkat disiplin yang sangat baik dari semua pegawai baik dari ketepatan absensi, kebersihan ruangan dan susunan meja, ruangan yang bebas asap rokok. PT. H hanya memiliki peraturan umum perusahaan dan belum memiliki peraturan kode etik secara tertulis. PT. H menekankan pentingnya kompetensi terhadap pegawainya, karena secara berkala dilakukan pelatihan serta dilakukan penilaian kinerja berdasarkan pokok-pokok tugas masing-masing pegawai. Struktur organisasi secara umum cukup memadai, tetapi ada kelemahan berupa pada tiap bagian tidak dicantumkan secara jelas dan terperinci tingkatan dan personel yang terkait. PT. H tidak memiliki auditor internal, selama ini penilaian risiko hanya dilakukan oleh manajemen yaitu tiap unit atau subbidang sehingga tidak memiliki laporan hasil audit internal. Aktivitas pengendalian dari hal pemisahan tugas dan sistem otorisasi sudah dilakukan dengan baik. Sedangkan terhadap pengelolaan dokumen secara umum telah dilakukan dengan baik karena rancangan formulir jelas, mudah dimengerti dan mempermudah pendataan. Akan tetapi, ada beberapa kelemahan yaitu tidak semua formulir bernomor urut tercetak, kemudian lambatnya penerimaan berkas dari bank perantara.

Pengendalian secara fisik telah memadai dilihat dari perusahaan mendata setiap tamu atau pelanggan yang datang, kunci perusahaan hanya dipegang oleh security perusahaan sehingga tidak ada personel lain yang memiliki kuci ruangan kemudian perusahaan memiliki ruangan khusus untuk menyimpan dokumen-dokumen penting dan akses ke dalam ruangan tersebut hanya dimiliki oleh personel yang berwenang. PT. H memiliki lima informasi akuntansi yaitu laporan keuangan, laporan solvabilitas, laporan realisasi anggaran, laporan arus kas, dan laporan outstanding utang klaim. Ada laporan yang belum dibuat oleh manajemen yaitu laporan piutang premi. Manajemen PT. H tidak memiliki cara atau standar komunikasi antarbagian dan sub-bagian.

Dari fakta-fakta di atas, ada beberapa hal yang menjadi pembahasan khusus yaitu kelemahankelemahan yang masih dimiliki, dimulai dari belum dimilikinya peraturan kode etik. Akibatnya adalah personel tidak mengetahui batasan secara pasti dalam bertindak dan berperilaku kemudian apabila terdapat masalah dengan pelanggan yang disebabkan salah bertindak maka dapat mencoreng nama baik perusahaan. Untuk mencegah hal tersebut terjadi lagi, maka PT. H sebaiknya membuat peraturan mengenai kode etik dan peraturan itu dengan jelas dikomunikasikan kepada seluruh personel.

Selanjutnya mengenai bagan struktur organisasi perusahaan secara keseluruhan yang pada tiap bagian tidak dicantumkan secara jelas dan terperinci tingkatan dan personel yang terkait dapat 
menyebabkan beberapa masalah yaitu kurang jelasnya garis atau alur wewenang dan tanggung jawab, kedudukan dan pengelompokkan satuan-satuan organisasi tidak terlihat secara jelas. Kemudian semua jabatan yang ada tidak dapat terlihat jelas. Oleh karena itu, sebaiknya PT. H menyusun bagan organisasi secara terperinci satuan organisasi atau bagian perusahaan.

PT. H belum memiliki auditor internal dapat mengakibatkan beberapa permasalahan yaitu sulitnya mengidentifikasi risiko yang relevan secara keseluruhan apabila tidak ada monitoring dan evaluasi dari pihak independen serta sulit menentukan tindakan yang harus dilakukan untuk mengurangi risiko-risiko tersebut samapai dengan tingkat yang dapat diterima. Oleh karena itu, perusahaan sebaiknya perusahaan memiliki fungsi auditor internal sehingga dapat menilai risiko-risiko yang dapat menghambat kinerja, memantau dan mengevaluasi operasional perusahaan agar lebih efektif dan efisien.

Pengelolaan beberapa dokumen yang tidak bernomor urut tercetak dapat mengakibatkan beberapa hal yaitu meningkatnya kemungkinan pencatatan nomor urut dua kali atau terlongkap, kemudian dapat mengacaukan pencatatan apabila terdapat nomor yang sama atau telongkapnya nomor urut dan karena kurangnya pengawasan dalam penggunaan formulir maka pertanggungjawaban atas jumlah transaksi menjadi sulit. Masalah pengelolaan dokumen selanjutnya yaitu lambatnya penerimaan dokumen akibatnya dapat memperbesar kemungkinan adanya dokumen yang hilang karena dokumen tidak segera dikirimkan ke PT. H dari bank perantara kemudian pencatatan PT. H menjadi tidak up-to-date. Oleh karena itu, PT. H perlu menetapkan kebijakan batas waktu pengiriman berkas serta melakukan pencocokan softfile, rekening koran dan berkas-berkas hardcopy ketika telah sampai di perusahaan sehingga tidak menumpuk pada akhir bulan.

Laporan piutang premi yang selama ini belum disusun oleh perusahaan dapat mengakibatkan tidak tercerminnya keadaan piutang PT. H secara terperinci karena informasi mengenai kondisi penagihan piutang, kondisi pelunasan piutang serta evaluasi umur piutang kurang terlihat. Oleh karena itu, untuk memperjelas informasi tentang piutang premi perusahaan maka PT. H segera menyusun laporan piutang premi yang terdiri dari laporan penagihan piutang, laporan pelunasan piutang dan laporan evaluasi umur piutang.

\section{Evaluasi Pengendalian Internal dan Sistem Akuntansi atas Penjualan PT. H}

Evaluasi terhadap pengendalian intern dan sistem akuntansi mendapatkan fakta-fakta yang ada di PT. H. Ada fakta-fakta yang merupakan kelebihan dan fakta-fakta kelemahan yang masih ada. Fakta-fakta yang diperoleh adalah sebagai berikut.

Untuk mendapatkan asuransi produk asuransi PT.H terdapat beberapa hal yang unik dan berbeda dari perusahaan-perusahaan asuransinya yaitu hanya menerima permintaan asuransi secara kumpulan dan tidak melayani perorangan, untuk satu permintaan asuransi jiwa kumpulan terdapat minimal 15 jiwa calon tertanggung dan yang memegang polis hanya pihak asuransi, bank dan perusahaan atau sekolah atau mitra. Para tertanggung hanya menerima kartu peserta karena merupakan asuransi jiwa kumpulan. Untuk penilaian risiko semua dokumen berupa form dan berkas kelengkapan dicek oleh underwriter untuk dipastikan bahwa semua data tersebut valid, setelah itu baru dapat diterbitkan surat akseptasi asuransi jiwa. Pemisahan tugas telah dilakukan dengan baik karena bagian pemasaran atau marketing terpisah dari bagian yang mencetak polis asuransi, kemudian bagian marketing terpisah dari bagian penerimaan kas dan piutang premi asuransi.

Fungsi otorisasi juga berjalan dengan baik pada fungsi penjualan karena semua pemberian asuransi divalidasi secara ketat untuk dipastikan data-data dari pihak tertanggung benar-benar valid. Dokumentasi pada fungsi penjualan juga lengkap dan dapat menangkap semua data yang diperlukan oleh proses penjualan asuransi. Pada umumnya, pengendalian internal dan Sistem Akuntansi atas penjualan sudah berjalan baik mengenai penjualan asuransi yang dilakukan secara kumpulan 
merupakan pilihan bagi PT. H yang dianggap efektif dan efisien sesuai dengan operasional bisnis perusahaan. Selain itu terpisahnya fungsi marketing dengan fungsi lainnya terkait penjualan sudah sangat baik karena terkait dengan komisi yang akan diperoleh oleh bagian marketing.

\section{Evaluasi Pengendalian Intern dan Sistem Akuntansi atas Penerimaan Kas PT. H}

Evaluasi terhadap pengendalian intern dan sistem akuntansi penerimaan kas mendapatkan fakta-fakta yang ada di PT. H. Ada fakta-fakta yang merupakan kelebihan dan fakta-fakta kelemahan yang masih ada. Fakta-fakta yang diperoleh adalah sebagai berikut.

Penerimaan kas pada PT H dari titipan premi asuransi yang timbul pada saat bank, mitra atau agen telah mentransfer pembayaran premi ke perusahaan dan berkas-berkas atau dokumen-dokumen telah diterima oleh perusahaan. Berdasarkan evaluasi dari kuesioner, PT. H telah memberikan dan membagi tugas kepada personel sesuai dengan jabatan dan kemampuan mereka. Perusahaan juga telah menerapkan sistem rotasi pekerjaan bagi personelnya, hal tersebut dilakukan guna untuk mencegah adanya kejenuhan dalam menyelesaikan pekerjaan dan dapat mengurangi risiko terjadinya kolusi antarkaryawan untuk melakukan fraud. PT H telah melakukan pemisahan tugas sesuai dengan kebijakan yang telah dibuat oleh perusahaan dan dapat meminimalkan adanya kesempatan atau kemungkinan adanya human error maupun kesempatan para personel untuk koalisi dan melakukan fraud.

Apabila terjadi pergerakan uang di kasir, harus ada approval dari Bagian Akuntansi dan Keuangan. Hal tersebut diharapkan agar tidak adanya penyalahgunaan kas kecil. Pada PT. H telah dibuat sistem keamanan untuk brankas kas, terdapat masing-masing dua orang pemegang kunci dan kode. Pemegang kunci tidak boleh mengetahui kode, dan begitu juga sebaliknya, sehingga pada saat membuka brankas harus ada pemegang kunci dan kode. Penerimaan kas atau titipan premi bermula dari pembayaran premi asuransi yang sudah diterima oleh perusahaan namun masih belum menerima berkas-berkas, yaitu permintaan pembayaran, kwitansi, serta daftar peserta. Yang menjadi dasar pencatatan dan pencocokan dari titipan premi adalah softfile Daftar Peserta dan rekening koran harian.

PT. H melakukan rekonsiliasi dengan pihak bank, mitra atau agen dengan cara mencocokkan rekening koran dengan berkas-berkas atau dokumen yang telah diterima oleh Bagian Pertanggungan. Sama halnya pada piutang premi. Apabila terjadi perbedaan atau selisih antara besarnya dokumen dan data softcopy, maka akan dilakukan rekonsiliasi dan memberitahukan pihak yang terkait. Evaluasi terhadap pengendalian internal dan sistem akuntansi atas penerimaan kas secara umum sudah memadai sehingga harus dijaga konsistensi penerapan aturan terkait prosedur dan sistem akuntansi penerimaan kas.

\section{Evaluasi Pengendalian Intern dan Sistem Akuntansi atas Piutang Premi PT. H}

Evaluasi terhadap pengendalian internal dan sistem akuntansi piutang premi mendapatkan fakta-fakta yang ada di PT. H. Ada fakta-fakta yang merupakan kelebihan, dan juga fakta-fakta kelemahan masih ada. Fakta-fakta yang diperoleh adalah sebagai berikut.

Pada PT. H, piutang premi timbul pada saat perusahaan menerima uang pembayaran premi yang ditransfer oleh bank, mitra, maupun agen namun masih belum menerima berkas-berkas atau dokumen hardcopy untuk periode bulan sebelumnya. Perusahaan melakukan pencocokan menggunakan softcopy yang diberikan oleh bank, mitra, maupun agen pada tiap akhir bulan. Misalnya, pembayaran premi yang telah dikumpulkan Bank BRI selama bulan Januari baru akan ditransfer ke PT $\mathrm{H}$ pada bulan Februari. Setelah Bank BRI melakukan transfer ke perusahaan, pihak bank akan memberikan softcopy rekapitulasi dari pada tertanggung. 
Perusahaan telah melakukan pengecekan dari Daftar Peserta dengan rekening koran harian untuk memastikan tidak adanya kesalahan pencatatan dan untuk memastikan seluruh transaksi telah benar tercatat. Personel yang membuat catatan kartu piutang premi berbeda dari yang mengerjakan buku besar. Hal tersebut dapat meminimalisasi terjadinya lapping yang rentan terjadi pada piutang perusahaan. Dokumentasi piutang premi secara umum sudah baik karena semua dokumen lengkap dan jelas serta meng-cover seluruh informasi yang dibutuhkan dalam piutang premi. Akan tetapi, ada kelemahan dalam hal softfile dari daftar peserta, baru dimiliki pada akhir bulan.

Pencatatan atas transaksi penjualan asuransi jiwa kumpulan terdapat lampiran dokumendokumen atau berkas yang lengkap sehingga dapat lebih menjamin kebenaran dari pencatatan tersebut. Piutang dicatat pada saat perusahaan menerima pembayaran premi (piutang premi) dari bank atau agen, tetapi belum menerima dokumen dan berkas hardcopy. Bagian Pertanggungan akan melakukan pencocokan berkas-berkas Surat Permintaan Pembayaran, Daftar Peserta, Faktur Pajak, dan Kwitansi dengan transaksi yang terdapat pada rekening koran untuk di upload ke sistem. Apabila terdapat perbedaan maka akan melakukan rekonsiliasi dan mengkonfirmasi ke pihak bank atau agen.

Secara umum, pengendalian internal dan sistem akuntansi terhadap piutang premi sudah baik walaupun ada masalah dalam hal softfile dari daftar peserta yang baru dimiliki pada akhir bulan sehingga dapat menyebabkan meningkatnya kemungkinan adanya transaksi yang lupa atau tidak tercatat oleh pihak bank atau agen.Oleh karena itu, harus dibuat kebijakan bahwa data softfile daftar peserta harus terbaharui setiap hari.

\section{SIMPULAN}

Berdasarkan evaluasi yang telah dilakukan, pengendalian internal secara keseluruhan maupun yang berkaitan dengan penerimaan kas dan piutang premi asuransi PT H yang dibuat oleh manajemen sudah dapat melindungi aset dan meminimalkan risiko yang dapat menghambat kinerja dan operasional perusahaan. Namun, selain hasil evaluasi yang telah disebutkan di atas, dapat disimpulkan bahwa masih terdapat beberapa masalah yang harus diperhatikan dan menjadi pertimbangan manajemen PT $\mathrm{H}$, yaitu kurangnya pedoman tertulis dan konkret atas kode etik, penyampaian informasi, serta bagan struktur organisasi yang kurang terperinci. Masih terdapat masalah lain yang berkaitan dengan pencatatan yang tidak up-to-date yang disebabkan oleh lambatnya penerimaan berkas-berkas yang dijadikan dasar pencatatan memakan waktu satu sampai tiga bulan masa pengiriman. Selain keterlambatan dokumen, form atau berkas perusahaan masih ada yang tidak memiliki nomor urut tercetak.

Berdasarkan hasil evaluasi yang telah dijelaskan, rekomendasi dan saran yang mungkin dapat membantu manajemen dalam PT H untuk meningkatkan efektivitas kinerja dan operasional perusahaan khususnya dalam pencatatan dan pengakuan pendapatan premi asuransi dan penyampaian informasi. Rekomendasi-rekomendasi tersebut adalah: perusahaan membuat kebijakan baru yang secara jelas menyatakan berkas harus dikirim sehari setelah transaksi berlangsung dan sampai diperusahaan maksimal satu minggu lamanya; bagian pertanggungan melakukan pencocokan berkas dengan softfile setiap berkas sampai di perusahaan, tidak hanya di akhir bulan atau awal bulan selanjutnya; manajemen pada setiap bagian memiliki pedoman dan peraturan tertulis dalam bertukar informasi atau dokumen ke bagian lain atau subbagian masing-masing. Peraturan tersebut misalnya: peraturan permintaan dokumen atau data antarbagian, peraturan permintaan dokumen atau data antarsubbagian, manajemen membuat sistem penomoran urut tercetak pada setiap dokumen yang digunakan, dan manajemen membuat bagan struktur organisasi yang lebih terperinci dan jelas. 


\section{DAFTAR PUSTAKA}

Agoes, S. (2004). Auditing: Pemeriksaan Akuntan oleh Akuntan Publik. Jakarta: Lembaga Penerbit Fakultas Ekonomi Universitas Indonesia.

Ikatan Akuntan Indonesia. (2010). Standar Akuntansi Keuangan. Jakarta: Penerbit Salemba Empat.

Kieso, D. E., Weygandt, J. J., Kimmel, P. D. (2008). Accounting Principles. Wiley.

Messier, W. F., Glover, S. M., Prawitt, D. F (2006). Auditing \& Assurance Services. Edisi Empat. New York: The McGraw-Hill.

Mulyadi. (2002). Auditing. Jakarta: Penerbit Salemba Empat.

. (2004). Sistem Akuntansi. Jakarta: Penerbit Salemba Empat.

Warren, C. S., Reeve, J. M., Fress, P. E. (2005). Pengantar Akuntansi buku 1, (edisi 21). Penerjemah: Farahmita, Amanugrahani, \& T. Hendrawan. Jakarta: Penerbit Salemba Empat. 